\title{
36
}

\section{The Hope of \\ the Great Community}

These words are written at a moment when the issues of the great war are still undecided. They are founded upon no foresight of the course which the world's political and military fortunes are to follow. They therefore refer wholly to ideals, to duties, to hopes, and to the interests of humanity.

There are moments when the lover of mankind, in these days, seems to catch a glimpse of a wonderful dawn light. If this dawn soon gives place to the coming day, an era of inspiring promise for the best hopes of all human ages will begin. If the clouds persistently gather again, as at some moments they do; if the night returns, as, for all that the present writer can know, it may return,--then the world must wait again for centuries, and must wait in sorrow, for that which the wise and the faithful of many generations have longingly expected.

"More than they that watch for the morning," the true lovers of mankind now watch to see whether the seeming promise of the dawn is to be, in any genuine sense, fulfilled. More than the spoilers of mankind ever before scoffed at the hope of humanity, powerful enemies of the good now confidently look for the triumph of Satan. The outcome of the present struggle between good and ill remains still a mystery.

[Reprinted from $H G C$, pp. 25-7o.] 
All that one can hope to do at such a moment, is to try to clarify his ideas about what ought to be-wholly powerless as the lover of the ideal is to determine, through any skilfully devised engines of destruction, or through any efficiency of the general staff of any national army, what shall be. All that one can now utter must be called at best "A Song before Sunrise." We do not know whether the sun for which the genuine lovers of mankind and of the ideal long, will ever rise in any future which we human beings can foresee for our own race.

Every idealist believes himself to have rational grounds for the faith that somewhere, and in some world, and at some time, the ideal will triumph, so that a survey, a divine synopsis of all time, somehow reveals the lesson of all sorrow, the meaning of all tragedy, the triumph of the spirit. But it is not ours to say, in the world in which we at present have to live from one day to another, and to follow the fortunes of man from one newspaper to another,-when and how the true revelation of the world's meaning is faced and found. We often do our best when we fix our mind on the thought which Kant expressed in the words: "If justice meets utter wreck, then there is no worth whatever in the continued existence of human life in this world." That word, at least, relieves us from the requirement of trying to prove that justice in mortal affairs will escape total wreck.

Perhaps the time will come when, indeed, there will be no further worth in the continued existence of men on this planet. If the purposes and deeds which some of the powerful enemies of mankind now boastfully attempt to make successful ever become permanently triumphant, then in truth there will be no further worth in the continued existence of human beings. As a matter of fact, this planet has seen its "Age of Reptiles." The sabre-toothed tiger has also had its day. Perhaps the ideals of those who defend and praise the destruction of mothers and of their babes on the "Lusitania" represent the sort of humanity that is henceforth, for an indefinite time, to win possession of the powers which are to control the fortunes of human civilization. About such matters a genuine idealist has no philosophical right, just as he has no scientific right, to make any particular prediction. His business is with the justice whose nature is such that if here on earth it is permanently wrecked, then the life of man becomes utterly worthless. There are to-day boastful powers, 
as hopeful of their own success as Milton's fallen angels were when

\author{
Satan exalted sat, \\ By merit raised to that bad eminence,
}

on his throne before them, and made preparations for a sort of submarine campaign against the salvation of man. The lover of ideals has no more right to make predictions about the hopes of these boastful powers, than Milton's good angels would have had to make predictions about the results of Satan's subsequent search for this little earth, and about what his visits to the Garden of Eden would accomplish.

In Milton's tale these visits accomplished the Fall of Man. The good and the bad angels have been struggling for the final possession of man ever since. The struggle continues to-day. And there can be no doubt that the evil powers are prodigiously efficient, and that the servants of ill are devotedly loyal to their diabolical cause. As for humanity, man, like the sabre-toothed tiger, may ere long have had his day and may have ceased to be. The lover of ideals can make no predictions as to such results. He can only "watch for the morning" until, for him and for some of his human fellows, the darkness has indeed settled down. It remains, however, still worth while to tell what hopes one's "Song before Sunrise" would express if one were permitted not merely to watch and sometimes to hope for the morning, but to tell what the sun would show us if it had already risen for humanity, or will show us whenever for humanity it does rise, if indeed on this planet it ever is to rise.

\title{
I
}

In order rightly to estimate the ideal issues which are at stake in the present crisis of humanity, it is first necessary to make clear a matter concerning which there is a good deal of confusion in recent discussion. Some of this confusion is benevolent and wellmeaning; some of it is due to wilful disregard of certain ethical issues which ought to be as obvious as they are deep. The matter to which I refer can best be brought nearer to clearness by contrasting two views of the world's present moral situation which frequently appear in recent expressions concerning the morals of the war. According to one of these views, the present war is essentially a conflict 
between nations and between national ideals. The essence of this doctrine is, that just as the conflicting powers are nations, so the main moral concern ought to be expressed in hopes that this or that nation will obtain a deserved success.

Opposed to this view is a second and very different view of the moral situation of the world and of the meaning of the war. According to this view, the present war is a conflict more conscious, more explicit, and for that very reason more dangerous than any we have ever had before, a conflict between the community of mankind and the particular interests of individual nations. Consequently, no nation engaged in this war is, or can be, right in its cause, except in so far as it is explicitly aiming towards the triumph of the community of mankind. As a fact, the various warring nations are at present acting with a decidedly various degree of clearness about their relation to the unified interests of humanity; that is, to what I call the cause of the community of mankind. Hence the various nations differ in the degree to which, at any stage of the conflict, their cause is just. In certain respects and with regard to certain of their enterprises, they may be, and are, explicitly aware that they intend to serve the community of mankind; while in other respects, or in regard to other matters, they may act with a more or less explicitly deliberate hostility to the cause of the community of mankind. Their moral position may, therefore, vary accordingly. But owing to the vastness and to the definiteness of many of the special international passions and issues concerned in the present conflict, the outcome of the war promises to be either a victory or a defeat, not for any one of the warring nations nearly so much as for humanity in its wholeness, and hence for what I shall venture also to call the church universal. It is important, therefore, to indicate as clearly as possible what in this discussion I mean by the community of mankind, and what by the church universal.

Ancient Israel somewhat early reached a religious ideal which it expressed in the doctrine of some of its Prophets, that the redeemed and transformed Jerusalem of the future was to be the centre of a redeemed humanity, the spiritual ruler of a kingdom which should have no end. In reaching this ideal, the religion of the Prophets did not look forward merely to a political conquest of the rest of the world by the future people of Israel. The ideal of the transformed humanity of the future had, indeed, in case of the religion of the Prophets, its political metaphors and inevitably its political color- 
ing. The subsequent results when the ideal religion of the Prophets degenerated into the formalities of later Judaism, were in many ways disastrous both for the morals and for the religion of Judaism. But the ideal city of Zion, the centre of a new heaven and earth, passed over as an ideal into the possession of the early Christian church. The Apostle Paul gave to its inner life the character which he called "charity," and which he expounded to the Corinthians in one of the greatest documents of Christian literature.

The often misunderstood heart and essence of the Pauline vision of charity is that it is a virtue belonging to a community, a community which Paul conceives as finding its future home in a heaven where the Divine Spirit both informs it and fulfils its life and its desire. Charity does not mean mere love of individuals for individuals; since if, according to Paul, I gave all my goods to feed the poor, and my body to be burned, I might still be without charity, and then be as a sounding brass or as a tinkling cymbal. Charity, for Paul, is not a merely mystical power to prophesy, nor does it consist in any other form of merely individual efficiency or proficiency. It is a virtue which Paul recommends to his Corinthians as to an united community who, in the bonds of the spirit, are one body despite the multitude of the members. Charity never faileth, and outlasts all earthly vicissitudes in its own heavenly world, because there we know even as we are known, and our mutual relations are those of a perfected spiritual community.

Paul viewed the salvation of humanity as consisting in the triumph of the Christian church. This triumph was for him something miraculous, catastrophic, and future; and his expectations regarding the triumph and end of humanity were obviously quite mythical. But this triumph of humanity, this hope of all the faithful, this salvation of a community through an universally significant human transformation, without which no salvation of an individual man would be possible, this idea, in terms of which the Apostle Paul universalized the ideal Jerusalem of the early Prophets, this became the most essential and characteristic idea of the Christian church.

The historical church has never been true to it and has seldom understood it. Most Christians suppose that the salvation of men is an affair involving the distinct, and in many ways the isolated, spiritual fortunes of individual men. Such Christians, however, have not understood what the vision of the New Jerusalem was in which the seer of the Apocalypse gloried. What the tree of life bears for 
the healing of the nations, such Christians have never rightly comprehended. What the farewell address of the Logos of the Fourth Gospel meant, when the departing Lord prayed to the Father, "That those whom Thou has given me may be One as We are One," such individualistic Christianity (which has been only too popular in the various Protestant sects) has neglected, if not forgotten. But however ill-comprehended, the "sign" in which and by which Christianity conquered the world was the sign of an ideal community of all the faithful, which was to become the community of all mankind, and which was to become some day the possessor of all the earth, the exponent of true charity, at once the spirit and the ruler of the humanity of the future.

Such is a bare suggestion of that ideal of the community of mankind which it was the historical mission of Christianity to introduce into the world, to keep alive through centuries of human crimes, oppressions, rebellions, and hatreds, and to hold before the world for the healing of the nations. The present situation of humanity depends upon the fact that for good reasons, which have to do not merely with the sentimental and romantic aspirations of humanity, but also with the most serious business in which men are engaged, the idea of the community of mankind has become more concrete, more closely related to the affairs of daily life, has become more practicable than ever before. At this very moment the material aspect of civilization favors, as never before, the natural conditions upon which the community of mankind, if it were reasonably successful, would depend for its prosperity. The growth of the natural sciences as well as of the technical industries of mankind also makes possible and comprehensive forms and grades of coöperation which men have never before known. Some motives which tend to render the genuine Pauline charity, the genuine love of the unity of the great community to which all civilized men may, when enlightened, consciously belong,--such motives, I say, have been furthered by the arts, the industries, the sciences, and the social developments of the nineteenth and twentieth centuries, as thousands of years of previous human activity have never furthered them. The brilliant coloring, the luxuriant images with which the fancy of the seer of the Apocalypse adorned his New Jerusalem, readily suggest themselves to the imagination of the lover of human kind, who dwells on some of the more benign aspects of our recent civilization, and who considers how far-reaching the abundant powers 
of human life are tending to become under the influence of those humane arts and sciences which of late have so successfully combated disease, and have brought together nations and races of men who once could not in the least feel their brotherhood, or mutually understand the tongues which they spoke.

These benevolent and benign influences do not, indeed, of themselves constitute the true Pauline charity; but within the last two centuries we have for the first time seen glimpses of how, under perfectly human conditions, they could become a basis for a charity which might transform our society in many of its most significant features into a social order worthy both of a new heaven and of a new earth. In brief, the last two centuries have given us a right to hope for the unity of mankind, a right of which we had only mythical glimpses and mystical visions before. This right we gained through the recent development both of our natural sciences and of our modern humanities. The idea of the human community has tended of late to win a certain clearness which it never could possess until now.

Paul could believe in his vision of the redeemed humanity of the future, because he had his own perfectly concrete and human, if to him unsatisfactory, experiences of the apparently miraculous life which was present in his enthusiastic little churches. When he talked of the redeemed humanity in heaven, and had his vision of the charity that never faileth, he could say to his brethren: "Thus the Spirit manifests itself amongst you." When, in an unquestionably more fantastic manner and language, the author of the Fourth Gospel made the speaker of the farewell addresses characterize the present life and the future life of his little company of disciples, whom "having loved them, he loved them to the end," the writer of this Gospel could use his concrete, although historically idealized, portrait of the last meeting between the Lord and his disciples as the basis and background of this vision of the salvation of mankind.

In our day this vision of the salvation of mankind, while indeed far enough away from us to cause constant and grave concern, and to demand endless labor, has been for a long time becoming clearer than ever, while both science and industry have tended to bring men together in new fashions of coöperation, in new opportunities and exercises that involve an expressed charity in its true form, as a devotion not merely to individuals but to the united life of the community. The belief that mankind can be and in the end shall 
be one, has thus for a long time had an increased concreteness, definiteness, practical applicability, and despite all the vast evils of our modern social order, a genuine hopefulness. What has to be borne in mind is, that in former centuries, and above all in ancient times, the community of mankind was hindered from becoming an object either of experience or of reasonable hope by the confusions of men's tongues, by the mutual hostilities of nations, of religions, and of sects, and by the absence of means whereby men might learn to work together. Since the beginning of the modern world, not only have the sciences and the arts helped us to work together in a material way and to understand one another regarding our various ideas, but very many of our modern intellectual and practical modes of progress have possessed a significance not only material, but deeply spiritual and, what is more to the point in our present discussion, wisely international. The modern world has become in many ways more and more an international world. And this, I insist, has been true not merely as to its technical and material ties, but as to its spiritual union.

It has been this vision upon which a recent international crime has so violently intruded. The hope of the community lies in trying to keep before us a vision of what the community of mankind may yet become despite this tragic calamity.

\section{II}

In speaking at such a moment of the community of mankind viewed simply as an ideal of the future, there are two matters which, as I believe, we ought to bear in mind. First, its members will not be merely individual human beings, nor yet mere collections or masses of human beings, however vast, but communities of some sort, communities such as, at any stage of civilization in which the great community is to be raised to some higher level of organization, already exist. Ethical individualism has been, in the past, one great foe of the great community. Ethical individualism, whether it takes the form of democracy or of the irresponsible search on the part of individuals for private happiness or for any other merely individual good, will never save mankind. Equally useless, however, for the attainment of humanity's great end would be any form of mere ethical collectivism, that is, any view which regarded the good of mankind as 
something which masses or crowds or disorganized collections of men should win.

For this reason Bentham's utilitarianism, in the form which he gave to it, and which the English political Liberals of the middle of the nineteenth century emphasized, does not express what the community of mankind needs for its existence and for its general welfare. That is why mere philanthropy, merely seeking for the greatest happiness for the greatest number, merely endeavoring to alleviate the pains of individual men or of collections of men, will never bring about the end for which mankind has always been seeking, and for the sake of which our individual life is worth living. That, too, is the reason why at the present time many humane people, despite their former horror of war, in view of its sorrows and of the misery which it causes, find to their surprise that, as Mr. Robert Herrick has said in a recent number of "The New Republic," war seems to them now no longer as great an evil as it used to seem; for in each of the warring peoples the war has brought about new consciousness of unity, a new willingness to surrender private good to the welfare of the community, a new sense of the sacredness of duty, a new readiness to sacrifice.

Such converts to the doctrine that war is good ascribe their sudden conversion to the wonder and reverence which have been aroused in them by the sight of France regenerated through the very dangers which the invader has brought with him, awakened to a new sense that the value of life lies not in what individuals get out of it, but in what the exertions and the perils of war call out and illustrate, namely, the supreme and super-individual value of loyalty. Loyalty, the devotion of the self to the interests of the community, is indeed the form which the highest life of humanity must take, whether in a political unity, such as in a nation, or in the church universal, such as Paul foresaw. Without loyalty, there is no salvation. Therefore loyalty can never completely express itself in the search for individual happiness, whether the happiness that is in question be that of the individual who teaches, or that of the mere collections of masses of individuals for whom some philanthropist seeks happiness.

Therefore it is indeed true that, if the only alternative for mankind were either to continue the arts of war or to lose its vision of high attainment in the form of a mere search for happiness, then it would 
be better that war should rage, with all its horrors, so long as humanity lasts, rather than that what Emerson called "hearts in sloth and ease" should live in an endlessly dissatisfied search for pleasures which deceive and which fade in the enjoyment, and for a happiness which no human individual can possibly attain, unless indeed he is viewed as a member of the community.

The detached individual is an essentially lost being. That ethical truth lies at the basis of the Pauline doctrine of original sin. It lies also at the basis of the pessimism with which the ancient southern Buddhism of the original founder of that faith, Gotama Buddha, viewed the life of man. The essence of the life of the detached individual is, as Gotama Buddha said, an unquenchable desire for bliss, a desire which "hastens to enjoyment, and in enjoyment pines to feel desire." Train such a detached individual by some form of highly civilized cultivation, and you merely show him what Paul called "the law." The law thus shown he hereupon finds to be in opposition to his self-will. Sin, as the Pauline phrase has it, "revives."

The individual, brought by his very cultivation to a clearer consciousness of the conflict between his self-will and the social laws which tradition inflicts upon him, finds a war going on in his own members. His life hereupon becomes only a sort of destruction of what is dearest to him. For as a social being, he has to recognize both the might of his social order and the dignity of its demands. But as a detached individual, he naturally hates restraint; that is, as Paul says, he hates the law. However correct his outward conduct may be, he inwardly says: "Oh, wretched man that I am, who shall deliver me from the body of this death?"

Such is the picture of the essentially disastrous life of the detached individual which you find in the much misunderstood, and in our day comparatively unpopular seventh chapter of the Epistle to the Romans. In the following chapter, Paul characterizes the only mode of salvation which can be offered with any hope to such a detached individual. Gotama Buddha sought the salvation of the detached individual through an act of resignation whereby all desires are finally abandoned. Paul describes what is essentially salvation through loyalty, salvation through the willing service of a community, the salvation of those whom he characterizes by the words: "They are in Christ Jesus, and walk not after the flesh, but after the spirit." But for Paul the being whom he called Christ Jesus was in essence the spirit of the universal community. 
The lesson with regard to which both Buddhism and Christianity agree, is the lesson that for the detached individual there is no salvation. Since, therefore, you can never make the detached individual securely and steadily happy, it is useless to try to save him, or any mere crowd or collection of detached individuals, by mere philanthropy. Since the detached individual is essentially a lost being, you cannot save masses of lost individuals through the triumph of mere democracy. Masses of lost individuals do not become genuine freemen merely because they all have votes. The suffrage can show the way of salvation only to those who are already loyal, who already, according to their lights, live in the spirit, and are directed not by a mere disposition to give good things to everybody, or to give all their goods to feed the poor, or to give their body to be burned, but by a genuinely Pauline charity.

Since then, it is only the consciously united community-that which is in essence a Pauline church-which can offer salvation to distracted humanity and can calm the otherwise insatiable greed and longing of the natural individual man, the salvation of the world will be found, if at all, through uniting the already existing communities of mankind into higher communities, and not through merely freeing the peoples from their oppressors, or through giving them a more popular government, unless popular government always takes the form of government by the united community, through the united community, and for the united community.

Therefore, while the great community of the future will unquestionably be international by virtue of the ties which will bind its various nationalities together, it will find no place for that sort of internationalism which despises the individual variety of nations, and which tries to substitute for the vices of those who at present seek merely to conquer mankind, the equally worthless desire of those who hope to see us in future as "men without a country." Whatever that form of loyalty which is now patriotism expresses, must be in spirit preserved by the great community of the future. That unity within the national growth which the observers of the war watch with such fascination, when they see how each people is better knit and more serious, more conscious of the sacredness of its national life than it was before the great peril, that unity will not, and must not, be lost when the new international life comes into existence. There can be no true international life unless the nations remain to possess it. There can never be a spiritual body unless that body, like 
the ideal Pauline church, has its many members. The citizens of the world of the future will not lose their distinct countries. What will pass away will be that insistent mutual hostility which gives to the nations of to-day, even in times of peace, so many of the hateful and distracting characters of a detached individual man. In case of human individuals, the sort of individualism which is opposed to the spirit of loyalty, is what I have already called the individualism of the detached individual, the individualism of the man who belongs to no community which he loves and to which he can devote himself with all his heart, and his soul, and his mind, and his strength. In so far as liberty and democracy, and independence of soul, mean that sort of individualism, they never have saved men and never can save men. For mere detachment, mere self-will, can never be satisfied with itself, can never win its goal. What saves us on any level of human social life is union. And when Webster said, in his familiar reply to Hayne, that what alone could save this country must be described as "Liberty and Union, now and forever, one and inseparable!"-Webster expressed in fine phrase, and with special reference to this country, the true doctrine of the church universal.

Liberty alone never saves us. Democracy alone never saves us. Our political freedom is but vanity unless it is a means through which we come to realize and practise charity, in the Pauline sense of that word. Hence the community of mankind will be international in the sense that it will ignore no rational and genuinely selfconscious nation. It will find the way to respect the liberty of the individual nations without destroying their genuine spiritual freedom. Its liberty and union, when attained, will be "now and forever, one and inseparable."

\section{III}

I have now mentioned one character which, as I believe, must belong to the international community of the future. Hereupon I must turn to a second character, which seems to me of equal importance with the first, although reformers and the creators of Utopias have almost uniformly neglected, or misunderstood this second character.

The distinct national unities must remain intact, each with its own internal motives for loyalty and with its modes of expression whereby the loyalty of its individual citizens will be won and sus- 
tained in the community of mankind, which the ideal future must contain if humanity is to be really saved. In the far-off future, as in the past, humanity will include amongst its number nations whose citizens belong not merely to various national types but to distinct races. No dream of universal conquest, if it were carried out, could ever lead to anything but to a more or less universal community of hate, to a social world essentially distracted, much as the world of the Gentiles, depicted by Paul at the outset of the Epistle to the Romans, was distracted. In and for such a community, no man, still less a nation, could deeply feel or long retain any genuine loyalty. Neither the pan-Germanists nor the pan-Slavists, neither the partisans of the white race nor those who hope for the supremacy of the yellow race, have any true conception of what the community of mankind is intended to be or of what the spirit of loyalty demands that it shall be. Both the nations and the races are needed for the future of mankind. The problem of humanity is to see that their liberty and their union shall remain "forever one and inseparable."

But what the lovers of national rivalries, who look forward to an endless strife of peoples, as well as the makers of the Utopias of universal peace, have equally failed to see is that amongst the many social functions of a nation or, for that matter, of any human community, the political functions of such a community, at any rate, as they have been conceived and carried out up to the present time, are ethically amongst the least important.

Greece never attained political unity. To-day it rules the world, as Germany will never rule it, though its inventions and its efficiency should continue and grow for a thousand years. Greece rules a spiritual world, and rules it spiritually. No modern nation that has won political power has ever expressed its best contribution to humanity through this political power, or has ever made a contribution to the community of mankind which is nearly equal to the contribution made by Greece, and made by a nation which proved wholly incapable of political unity. The greatest rival which Greece has ever possessed as a contributor to the cause of the community of mankind is the nation Isracl-by which I mean, not the Israel whose history was rewritten from the point of view of later Judaism and was so misrepresented in what we call the Old Testament. The Israel of which I speak is the Irsael of the great formative period of the prophetic religion, the Israel whose re- 
ligious beginnings are sketched for us in that brief and impressive fragment of poetry called the Song of Deborah-the Israel whose maturer consciousness found its voice in Amos and Isaiah, and in the records of the prophetic literature. Even after its formative period was past, and after Judaism had nearly quenched the spiritual fire which had burned in the religion of the Prophets, Israel still gave us the Psalms, still expressed, in the great speeches which an unknown master put into the mouth of Job, ideas and problems which are with us to-day, and which will record some of the great problems of human destiny for all coming ages of mankind, just as the great Greek tragedians of the formative period of the Hellenic mind have spoken for all time. But Israel, like Greece, never won, and from the nature of the case could not win, a lasting political unity.

When we remember how all the highest products of the German mind have so far been the products of times when the national unity in a political sense was not yet attained, while the mightiest accomplishment of Prussian domination has thus far been that, like the base Indian of Othello's last words, this Prussian domination, in dealing with the magnificent ideal legacy of the Germanic mind, has simply "thrown a pearl away, richer than all his tribe"; and when we remember how an analogous rule holds in case of several other European nations, we are reminded that, on the whole, there seems to be some opposition between the political power of a nation and its power to contribute to the ideal goods of the community of mankind.

The political contributions of nations either to the unity or to the life of the great community are by no means their only or, on the whole, their principal contributions. For that very reason it is not wise to hope that when the Holy City of the community of mankind descends from heaven to earth, it will come in political form. According to a well-known tradition, the Master said: "My kingdom is not of this world, else would my servants fight." I do not think that this reported word of the Master represents what the ideal course of human progress ought to be. The ideal community of mankind, whenever it really descends from heaven to earth, will indeed appear in a definitely worldly fashion. If the ideal is approximately realized, the kingdom will be in this world, yet its servants will not fight, simply because they will be loyally engrossed in much better business than fighting. That upon which I 
here insist is, that in learning such business they will not principally be guided by political arts and motives.

\section{IV}

But if the great community is not to win its loyal consciousness through inventing new political forms and through depending upon political institutions for its principal advances, must it then be confined to "the empire of the air"? Must it always be dependent upon its poets and its prophets? or upon their brethren, the great scientific discoverers, the genuinely inventive leaders of thought? Must its kingdom be a wholly ideal kingdom? Must its fortunes be those which, in a somewhat disheartening sequence of faiths and of practices, have so far constituted the history of religion?

I do not believe this. I believe that the future will invent, and will in due time begin very actively and productively to practise, forms of international activity which will be at once ideal in their significance and business-like in their methods, so that we shall no longer be dependent upon the extremely rare and precious beings called prophets or poets, to show us the way towards the united life of the great community. I have recently ventured to point out certain ways in which international business is already approaching a stage wherein, if the spoilers do not indeed too seriously wreck or too deeply impair our progress, we may actively begin to further international unity, without in the least interfering with the free internal development of the social orders of individual nations. It is not at all necessary to look towards the triumph of Socialism or of any other equally revolutionary social tendency, whether political or non-political, in order to foresee possible modes of international unification, which, if they were once tried, if a fair beginning of some such international activity were made, would almost certainly prove to be self-sustaining as well as conducive to a mutual understanding amongst the nations.

There is, for instance, a type of business which has been invented only within a little more than a century. In origin it is due to no poet and to no prophet. It has already transformed the civilization of the principal nations of Europe. The transformation in question is nowhere, except by accident, very closely bound up with political changes. The social transformations which it has already 
wrought within the communities of single nations, are not due to the spread of socialistic doctrines or to any notable political tensions or strifes within the communities which have thus been influenced.

The form of business which I have in mind is the form known as insurance. Within the life of a single civilized people, it is capable of accomplishing an immense variety of types of social service. The internal organization of Germany itself has been prodigiously furthered, the social unity and the impressive efficiency of the German people have been in recent decades very vastly furthered by the use which Bismarck and those who followed him were led to make of various forms of "state insurance" and of "social insurance," largely as means of meeting the demands which the socialistic movement was already making upon the state in general. What has been proved is that the type of business called insurance is so plastic and has such vast direct as well as indirect effects, that, within a single nation, if the purpose is to give a community such unity and such organization as naturally hold the attention and win the practical loyalty of the members of the community, the insurance type of organization is the best type invented for the purpose in question. This is no place to speak of the details of recent social insurance which Germany has so largely and so successfully used. It is enough to say that the business of insurance depends upon devices which are, so to speak, essentially unifying, essentially reconciling, essentially such as to exemplify a type of social community to which in a recent book of my own I have ventured to give a name, not, as I hope, too technical.

An insuring financial organization, whether it be an ordinary corporation or, as in Germany's case, a state or a government, has what I may call a mediating, a reconciling, a unifying function. If you regard the insurer as an individual man-and such in special cases he may be,-he mediates between the interests of two persons whose concerns, apart from the work of the insurer, are subject to an often painful conflict. These two persons may be called "the adventurer" and "the beneficiary." The adventurer is somebody who takes a risk, a practically significant risk. Like all risks, this one does not affect the fortunes of the adventurer alone. For the adventurer has, or at some time in the future will have, heirs or successors, or a family or other co-adventurers, who may, or who under certain conditions will benefit by the adventurer's under- 
takings if they succeed, but who will otherwise get quite the reverse of benefit out of the adventurer's failure. Thus the interests of the adventurer and of his possible beneficiaries, who may or will win if he wins, or who may or will lose if he loses, stand in a relation involving a certain rivalry, a tension, a source of possible conflict of the most varied kind. In other words, the adventurer and the possible beneficiary constitute what, in my "War and Insurance," I have called "a dangerous pair" of human beings. That is, their conflicting interests may lead to misunderstandings, to mutual wrongs, and to personal and social unrest of the most varied sorts.

Into this "dangerous pair" the insurer, in case his insurance enterprise is well founded and successful, introduces a reconciling element. It is the nature of his business to guarantee the beneficiary against the losses with which in the course of his fortunes the adventurer may meet. In consequence the dangerous pair becomes a genuine community, whose type is triadic and whose form is that of all the communities which I call "communities of interpretation." These are groups whose members comprise within themselves either individuals or communities. But in each of these communities, one of the members has the essentially spiritual function or task of representing or interpreting the plans, or purposes, or ideas, of one of his two fellows to the other of these two in such wise that the member of the community whom I call the "interpreter" works to the end that these three shall coöperate as if they were one, shall be so linked that they shall become members one of another, and that the community of the whole shall prosper and be preserved.

In "War and Insurance" I have defended the thesis that, if the principle of insurance were introduced into international affairs, even in a very small degree, it would involve, first the creation of an entirely new sort of international body-namely, an "international board of trustees." The functions of this board would not be those of a court of arbitration. They would not be diplomatic functions. The board would have no political powers or duties whatever. Hence its functions would constitute an entire novelty in human history. How such a board would be possible, how its funds might be protected from predatory assaults and kept free from the danger of being risked in international quarrels, my book has in a general way explained. 
Since any reader of this book who may have time in the distractions of the present conflict to give it even the least careful attention, very naturally asks at once what common interests of the nations there are to insure, it is possibly worth while to say that in an article in The New York Times for July 25, 1915, I have pointed out certain international interests which, in fact, are greatly intensified by some of the conditions of the present conflict, and which are so definitely related to existing forms of the insurance business, that were a few nations at the close of the present war to appoint an international board of trustees to take practical charge of just these perfectly definable interests, and to treat them so as to meet the conditions which the nations concerned could readily agree upon without departing from fields of insurance that already exist and that have already acquired international importance, then a beginning in international insurance could actually be made at once upon the conclusion of the present war.

Were such an international board of trustees once appointed, were some such essentially simple and familiar type of insurance enterprise once undertaken, under perfectly reasonable and business-like conditions, a beginning would be made in a process that would, from the very first, tend to make the unity of the various nations of mankind something practical and obvious, as well as certain to possess, as time went on, more and more significance for all concerned in such a process. For, as a fact, there are certain forms of insurance which, as I have just said, are already international in their scope. At the close of the present war, some of these forms of insurance will be in need of new international devices to render them useful and prosperous under the new financial conditions that will inevitably succeed the conflict.

Nobody has as yet attempted to devise an international board of trustees fitted to take charge of such international social interests. But in the article to which I have referred, I have endeavored not merely to show how the still very distant ideal of an international insurance against risks directly connected with war would be valuable if we could secure such a form of international insurance, but also to show that a special type of international insurance would be perfectly practicable and business-like at the close of the present war, if a few nations were to agree upon a plan for appointing an international board of trustees and for intrusting to it the new enterprise. This new enterprise would involve no essen- 
tially new type of insurance. It would be based upon international needs which are already recognized, which have already created certain very successful corporations, which actually do an international business. To make these already existing types of insurance international in my present sense, only the explicit recognition of a suitable international organ is necessary.

This new international organ would not be political in its nature, would not attempt to do the work of "a league of peace," while of course it would have no sort of opposition to the formation of any league of peace which proves in the future to be practicable. The new type of international organ would be founded upon no international treaty such as would need or invite arbitration. The nations that entered into the new enterprise would merely intrust certain funds to the new international board of trustees, and would remain perfectly free to retire from all relations to the enterprise at any moment, by the device which any ordinary holder of an insurance policy can use at present, namely, by surrendering the policy to the board of trustees.

The effects of the new enterprise would be in the main indirect. That is, the new enterprise would meet an actual need, and if it were reasonably devised, would meet that need at once, and would in so far do good. But if successful, it would lead to new enterprises of the type. The principle of insurance would, however, be definitely introduced into international affairs. Once introduced, and once made in the least effective, that principle might, I believe, safely be left to vindicate itself and its power to bring to consciousness the great community of the future. The realm of peace may, indeed, be far enough away from our distracted human nature. But the way towards peace, the way towards the winning of self-consciousness for the great community, the way towards a genuine and practically effective coöperation of the nations, at once in the spirit of sound and business-like devotion, and in its primitive true Pauline charity,-that way already lies open. 
